Revista de la red interuniversitaria de estudios sobre las literaturas rioplatenses contemporáneas en Francia

$18 \mid 2018$

El río y la ciudad

\title{
Acaso sea el río
}

\section{Loreley El Jaber}

URL: http://journals.openedition.org/lirico/5763

DOI: $10.4000 /$ lirico.5763

ISSN: 2262-8339

Editor

Réseau interuniversitaire d'étude des littératures contemporaines du Río de la Plata

\section{Referencia electrónica}

Loreley El Jaber, «Acaso sea el río », Cuadernos LIRICO [En línea], 18 | 2018, Puesto en línea el 14 octubre 2018, consultado el 04 mayo 2019. URL : http://journals.openedition.org/lirico/5763 ; DOI: 10.4000/lirico.5763

Este documento fue generado automáticamente el 4 mayo 2019.

\section{cc) ()요}

Cuadernos LIRICO está distribuido bajo una Licencia Creative Commons Atribución-NoComercialSinDerivar 4.0 Internacional. 


\title{
Acaso sea el río
}

\author{
Loreley El Jaber
}

¿Qué puedo decir de un río que casi no conozco? ¿Qué puedo decir yo que no sé lo que es un bote atravesando el río? ¿Yo, que sólo nado en sueños? Empeñada en encontrar algo de mí ligado a esa masa de agua que me rehúye, de repente me veo: estoy leyendo. Entro al río, siento su olor, palpo su sustancia dejando rastro en mis manos. El Boga y el Viejo están entre los juncos, las piernas y las manos en el agua. No hablan, no hay nada que decir. El silencio es parte de la vida en el río. Suben al bote, bajan, vuelven a subir. No puedo imaginar cómo será transcurrir un tiempo empecinado en repetirse. Suspiro, desisto. Leo.

El Viejo dice que va a morirse y, como no podía ser de otro modo, muere. El Boga anda ahora solitario. Qué inmensidad de aguas recorre. No conozco ninguno de esos nombres, serán riachos -calculo- ,pero tampoco averiguo. Me dejo llevar por la historia que trama el río, por sus vaivenes, sus desconocidos colores. Hay un saber en esa soledad que quisiera desgajar de a poco, entonces releo aquella vieja novela con la que entré al río por primera vez, como si allí estuviera la clave de mi relación con el agua y su brillo.

El Boga anda en un bote marcado por millones de manos; por momento desea un barco de verdad, por momentos no, lo abraza con cuidado y acepta el futuro que establece el movimiento en el que va. No lucha contra la fatalidad que imprime el río, no hay oráculo que consultar, no es necesario, nada puede torcer los designios cambiantes del agua. Ese saber infinito se lee en su mirada sin destellos. Parece que los ojos del que sabe pierden el brillo que regala la duda.

Y de repente un dorado, un hombre-niño, un perro, un herido. El río y la sangre entreverados, el bote perdido, el cuerpo hundido en la zanja. Hay río y barro también, tierra cenagosa, tanto pie queriendo comenzar el mundo. Leo, releo. El río entra por la ventana del bar con la misma furia del viento que golpea la cara del Boga y estrella el barco semihundido y quiere dejar huella en el bote, que no para de bailar en el aire.

Miro a través del vidrio, el sol de verano ilumina los autos, aun a pesar de la bóveda verde que dibujan los grandes árboles de la avenida. Mis ojos, reflejados en el ventanal, se muestran opacos. No hay agua alguna, ni una estela siquiera contiene el negro que veo. Respiro café y acaricio el libro. Tengo que preguntar cuál es el viento del sudeste.

Buenos Aires, septiembre 2017 